\title{
REPORTS AND CORRESPONDENCE
}

\section{Social History Conference}

\section{Thomas Winter and Andrew Kersten \\ University of Cincinnati}

Panels addressing a variety of issues in American labor history were well represented at the Third Social History Conference, held at the University of Cincinnati on October 30, 1993. Featured sessions included "Race, Gender, and Work in the Gilded Age," "Labor and Community Organizing in the Late 19th-Century United States," "Race and Labor in the 1920s," "The State, Law, Labor, and Gender Relations in the 20th-Century United States," and "Labor and the Homefront in World War II."

Several panels focused on race and gender. On the panel, "Race, Gender, and Work in the Gilded Age," Dean Ferguson (Purdue University) presented a paper on informal black workers in Louisville, titled "'Living By Means Unknown to their Neighbors': Alley Life and the Makeshift Economy of Louisville's Blacks, 1865-1880." At the same session, Robin Bachin (University of Michigan) presented a paper on the ways in which the company attempted to construct gender at Pullman, titled "'The One Great Impediment': Working Women and Domesticity in Pullman, IL 1881-1894." Both papers made for an interesting contrast, as Ferguson took a "bottom-up" approach, while Bachin presented a view from the top down. Issues of race and social control over the work force also took center stage in Robyn Spencer's (Columbia University) paper, titled "Contested Terrain: The Mississippi Flood of 1927 and the Struggle to Control Black Labor." Spencer described the attempt of white planters to detain black sharecroppers and tenant farmers with the help of relief camp staff and National Guard troops during the 1927 Mississippi flood. She also explored how the relief camp experience changed the consciousness of the sharecroppers and tenant farmers.

Issues of community and class provided the focus in the session on "Labor and Community Organizing in the Late 19th-Century United States." David Stowell (SUNY Buffalo) gave a paper on middle-class support for striking railroad workers in 1877 . Challenging the notion that middle-class groups supported the workers due to shared republican values, Stowell argued that the key to understanding this cross-class cooperation was recognizing that the use of city streets by railroads was particularly damaging to the interests of such middle-class businessmen as grocers and saloon keepers.

In recent years, labor historians have taken a fresh look at the role of 
law and the state on workers and labor relations. Papers by Lisa Phillips (Purdue University) on "Female Labor Laws in the State of Indiana, 19131929," and by Margaret C. Rung (Mount Allison University) on "The State, Human Relations and Labor Relations: Management in the Federal Civil Service, 1939-1945" attested to this interest. Phillips's paper explored the role of the state in institutionalizing gender stereotypes through protective labor legislation for women. Rung argued that a drive for professional status and authority on behalf of personnel managers encouraged them to adopt a human-relations approach to management. It enhanced the professional status of personnel managers and allowed them to maintain a sexual division of labor.

The role of the state also received emphasis in the papers by Jonathan Z. Pollack (University of Wisconsin-Madison) on "The American Federation of Musicians' Recording Bans 1942-44 and 1948," and Jonathan Rees (University of Wisconsin-Madison) on "The US Army's seizure and Occupation of the Cudahy Brothers Company, 1944-1945." Both papers addressed issues of government-labor relations in contrasting ways. While the National War Labor Board did not hesitate to take over a defenserelated meatpacking plant, it had little success in influencing labor relations in the music industry.

In conclusion, although regrettably some of the sessions turned into rump panels due to last-minute withdrawals, the Third Social History Conference offered interesting perspectives on labor history.

\title{
North American Labor History Conference
}

\author{
Eric Fure-Slocum, Kim Nielsen, Dorsey Phelps, \\ Anthony Quiroz, Mark Stemen, and Paul Young \\ University of Iowa
}

Questions about workers' political lives and citizenship occupied a central place at the fifteenth annual North American Labor History Conference. David Montgomery's capstone address, "Democracy and the 'Free Market' Economy: Some Reflections on the Experience of Workers in the United States during the Nineteenth Century," superbly addressed many of these themes, while placing them in a larger context. Emphasizing the need to distinguish between democracy and the market economy, both historically and in contemporary discourse, Montgomery charted a history of workers' citizenship and industrial capitalism's "discipline of buying and selling" in the nineteenth century. In his account, citizenship was not simply an attained status but a highly contested arena in which the political and social 